\title{
Two new troglobitic species of Scleropactidae (Crustacea: Isopoda: Oniscidea) from Pará, Brazil
}

Ivanklin Soares Campos-Filho and Paula Beatriz Araujo

(ISCF, PBA) Laboratório de Carcinologia, Departamento de Zoologia, Universidade Federal do Rio Grande do Sul, Av Bento Gonçalves, 9500, 91510-070, Agronomia, Porto Alegre, Brasil. E-mail: (ISCF) ivanklin.filho@gmail.com; (PBA) pabearaujo@gmail.com

\section{Abstract}

The South America Scleropactidae includes 53 nominal species distributed in 14 genera. In Brazil, there are 16 species recorded in the north and southeast regions. Here, two new species of Scleropactidae are described based on material collected in caves in the state of Pará, both troglobitic and allocated in the genus Circoniscus. Circoniscus buckupi sp. nov. can be distinguished from its congeners by the long second article of antennal flagellum, inner endite of maxillula with a small hook-like spine at the apex, a long dactylar organ with pectinate apex conferring a knife-shaped appearance and the absence of schisma in adults. Circoniscus carajasensis sp. nov. can be distinguished from Circoniscus buckupi sp. nov. by the presence of schisma on pereionite 1 in adults and dactylar organ with a fringe appearance.

Key words: Circoniscus, cave, Neotropical.

\section{Introduction}

Approximately 300 troglobitic species of terrestrial isopods are recorded in 16 families (Taiti, 2004), including Scleropactidae. The South America Scleropactidae, to date, includes 53 nominal species distributed in 14 genera (Schmidt, 2007): Amazoniscus Lemos de Castro, 1967; Caecopactes Schmidt, 2007; Circoniscus Pearse, 1917; Colomboniscus Vandel, 1972; Colomboscia Vandel, 1972; Globopactes Schmidt, 2007; Heptapactes Schmidt, 2007; Microsphaeroniscus Lemos de Castro, 1984; Neosanfilippia Brian, 1957; Richardsoniscus Vandel, 1963; Scleropactes Budde-Lund, 1885; Scleropactoides Schmidt, 2007; Sphaeroniscus Gerstäcker, 1854 and Spherarmadillo Richardson, 1907. In Brazil, only the genera Amazoniscus (two species, one of them troglobitic), Circoniscus (eight species), Heptapactes (one species) and Microsphaeroniscus (five species) are recorded in the north and in the southeast regions (Souza and Lemos de Castro, 1991; Schmalfuss, 2003; Souza et al., 2006; Schmidt, 2007).

The family Scleropactidae has been considered paraphyletic (Leistikow, 2001; Schmidt, 2002; 2003; 2007; 2008), sharing two synapomorphies with Halophilosciidae and Philosciidae: (1) male pereiopods 1-4 with large fields of scales on the ventral face of merus and carpus, and (2) second antenna apical cone very slender, often longer than the apical flagellar article, provided with a pair of small lateral free sensilla (Schmidt, 2003).

The genus Circoniscus was proposed by Pearse (1917) to include C. gaigei. Souza and Lemos de Castro (1991) described three new 
species and proposed the schisma of pereionite 1 as synapomorphy, later confirmed by Schmidt (2007). The genus is known to occur in Brazil, in the states of Amazonas, Pará, Mato Grosso, Rio de Janeiro and São Paulo (Schmalfuss, 2003).

The present work describes the first troglobitic species of Circoniscus, based on material collected in caves in the state of Pará, in the municipalities of Parauapebas and Canaã dos Carajás. A diagnosis of the genus can be found in Schmidt (2007).

\section{Material and Methods}

The material examined herein is deposited in the Museu de Zoologia (MZUSP), Universidade de São Paulo, São Paulo, Brazil and in the Coleção de Crustáceos do Departamento de Zoologia, Universidade Federal do Rio Grande do Sul (UFRGS), Porto Alegre, Brazil. All material was collected by R. Andrade et al. as in labels.

\section{Systematics}

Scleropactidae Verhoeff, 1938

Circoniscus Pearse, 1917

Circoniscus buckupi sp. nov.

Figs. 1-3, 7

Types: Holotype: Male, Brazil, Pará, Parauapebas, FLONA Carajás (FLONA National Forest), N4E73 cave, 602'32"S - 5009'35”W, 19/II-04/III/2010, leg. R. Andrade et al., MZUSP 23755. Paratypes: Brazil, Pará, Parauapebas FLONA Carajás: 3 males, 1 female, N5S09 cave (606' 5008'W), 14-23/X/2009, leg. R. Andrade et al., MZUSP 23756.

Additional material: Brazil, Pará, Parauapebas, FLONA Carajás, 1 ovigerous female, N5S09 cave, 606' $-50^{\circ} 08^{\prime} \mathrm{W}$, 14-23/X/2009, MZUSP 23757; 1 male, 3 females, N5S07 cave, 606' S - 500.'W, 1423/X/2009, MZUSP 23758; 1 male, 1 female, N5S63/64/65 cave, 606'S - 5008'W, 15-21/
IX/2009, MZUSP 23759; 1 male, 1 female, N5S52/53 cave, $6^{\circ} 06^{\prime} \mathrm{S}$ - 5008'W, 14/III04/IV/2010, MZUSP 23760; 1 male, 1 female, N5S37 cave, 6 06 'S - 500.'W, 14/ III-04/IV/2010, MZUSP 23761; 2 males, 2 females, N4WS15 cave, 606'S - 5008'W, 20/ IV-04/V/2010, MZUSP 23762; 2 females, N4E73 cave, 602'32"S - 5009'35”W, 19/ II-04/III/2010, MZUSP 23763; 3 males, 12 females, 7 mancas, N4E08 cave, 602'32”S - 5009'35”W, 20/X-01/XI/2006, MZUSP 23764; 2 males, 8 females, 1 manca, N4E33 cave, 602'32”S - 5009'35”W, 08-12/II/2007, MZUSP 23765; 2 males, 8 female, 1 manca, N4E26 cave, 602'32”S - 5009'35"W, 08-12/ II/2007, MZUSP 23766; 3 males, 1 female, N4E22 cave, 602’32"S - 5009'35”W, 20/ X-01/XI/2006, MZUSP 23767; 1 male, 1 female, N4E62 cave, 602'32”S - 5009'35”W, 19/II-03/III/2010, MZUSP 23768; 1 male, 3 females, N4E15 cave, 602’32”S - 5009'35”W, 20/IV-04/V/2006, MZUSP 23769; 1 male, 1 female, N4WS15 cave, 606'S - 5008'W, 20/ IV-04/V/2010, MZUSP 23770; 1 female, N4E14 cave, 602'32"S - 5009'35”W, 20/ IV-04/V/2010, MZUSP 23771; 2 females, N4WS15 cave, 6004'S - 50¹1'W, 20/IV04/V/2010, UFRGS 4598; 1 male, 2 females, N4E14 cave, 602'S 5009'W, 20/X-01/ XI/2006, UFRGS 4599; 3 males, 2 females, N4E15 cave, $.6^{\circ} 02^{\prime} \mathrm{S}$ - $50^{\circ} 09^{\prime} \mathrm{W}, 20 / \mathrm{X}-01 /$ XI/2006, UFRGS 4600; 1 male, 2 females, 1 manca, N4E19 cave, 6 $02 ' S$ - 5009'W, 20/X-01/XI/2006, UFRGS 4601; 1 male, 2 females, N4E03 cave, $6^{\circ} 02^{\prime} \mathrm{S} 50^{\circ} 09^{\prime} \mathrm{W}, 20 / \mathrm{X}$ 01/XI/2006, UFRGS 4602; 1 male, 5 females, N4E21 cave, 602'S - 5009'W, 20/X-01/ XI/2006, UFRGS 4603; 1 female, N4E61 cave, 6 $6^{\circ} 02^{\prime} \mathrm{S}$ - 5009'W, 08-12/II/2007, UFRGS 4604; 1 female, N4E28 cave, $6^{\circ} 02^{\prime} \mathrm{S}$ - 5009'W, 08-12/II/2007, UFRGS 4605; 1 female, N4E26 cave, 602'S - 5009' W, 20/X-01/XI/2006, UFRGS 4606; 1 female, N4E11 cave, 602'S - 5009'W, 20/X-01/ XI/2006, UFRGS 4607; 1 female, N4WS13 cave, 604'S - 50¹1'W, 20/X-01/XI/2006, UFRGS 4608; 1 male, N4WS15 cave, 60.'S - 50¹1'W, 20/IV-04/V/2010, UFRGS 4609; 1 female, N4E07 cave, 6 $02^{\prime} \mathrm{S}-50^{\circ} 09^{\prime} \mathrm{W}$, 
20/X-01/XI/2006, UFRGS4610; 1 female, N4E34 cave, 602'S - 5009'W, 08-12/ II/2007, UFRGS 4611; 1 female, N4WS14 cave, 604'S - 50¹1'W, 20/X-01/XI/2006, UFRGS 4612; 1 female, N4E10 cave, 602'S - 5009'W, 20/X-01/XI/2006, UFRGS 4613; 8 females, N4E13 cave, 6 02 'S - 5009' W, 20/X-01/XI/2006, UFRGS 4614; 2 males, 6 females, 1 manca, N4E15 cave, 6 02 'S 5009'W, 20/IV-04/V/2010, UFRGS 4615; 2 males, 7 females, 6 mancas, N4E13 cave, $6^{\circ} 02^{\prime} \mathrm{S}-50^{\circ} 09^{\prime} \mathrm{W}, 20 / \mathrm{IV}-04 / \mathrm{V} / 2010$, UFRGS 4616; 1 male, 1 female, 3 mancas, N4E08 cave, 602'S - 5009'W, 20/IV-04/V/2010, UFRGS 4617; 1 male, 1 female, N4E19 cave, 602'S - 5009'W, 20/IV-04/V/2010, UFRGS 4618; 1 male, 2 females, N4E14 cave, 602'S - 5009'W, 20/IV-04/V/2010, UFRGS 4619; 3 males, 3 females, 1 manca, N4E22 cave, 602'S - 5009'W, 20/IV-04/V/2010, UFRGS 4620; 2 males 1 manca, N4E10 cave, 602'S - 5009'W, 20/IV-04/V/2010, UFRGS 4621; 1 male, 3 females, N4E21 cave, 602'S -5009'W, 20/IV-04/V/2010, UFRGS 4622; 1 male, N4E03 cave, 602'S 5009'W, 20/IV-04/V/20210, UFRGS 4623; 1 male, N4E16 cave, 602'S - 5009'W, 20/ IV-04/V/2010, UFRGS 4624; 1 female, 1 manca, N4E07 cave, 602'S - 5009'W, 20/ IV-04/V/2010, UFRGS 4625; 1 male, N4E02 cave, 602'S - 5009'W, 20/IV-04/V/2010, UFRGS 4626; 1 male, 1 female, N4E11 cave, 602'S - 5009'W 20/IV-04/V/2010, UFRGS 4627; 1 male, 1 female, N4E19 cave, 602'S 5009'W, 20/IV-04/V/2010, UFRGS 4628; 1 female, N4E02 cave, 602'S 5009'W, 20/IV04/V/2010, UFRGS 4629; 1 manca, N4E03 cave, 602'S - 5009'W, 20/IV-04/V/2010, UFRGS 4630; 1 male, 1 manca, N4E15 cave, 602'S - 5009'W, 20/IV-04/V/2010, UFRGS 4631; 1 female, N4E57 cave, $6^{\circ} 02^{\prime} \mathrm{S} 50^{\circ} 09^{\prime} \mathrm{W}$, 19/II-04/III/2010, UFRGS 4632; 1 male, 3 females, N4E72 cave, 602'S - 5009' W, 19/II04/III/2010, UFRGS 4633; 1 female, N4E89 cave, 6 $6^{\circ} 02^{\prime} \mathrm{S} 50^{\circ} 09^{\prime} \mathrm{W}, 19 / \mathrm{II}-04 / \mathrm{III} / 2010$, UFRGS 4634; 1 female, N4E51 cave, 602'S 5009'W, 19/II-04/III/2010, UFRGS 463; 2 females, N4E62 cave, 602'S - 5009'W, 19/II-04/III/2010, UFRGS 4636; 1 male, 1 female, N4E73 cave, 602'S - 5009'W, 19/II04/III/2010, UFRGS 4637; 1 female, N4E39 cave, 602'S - 5009'W, 19/II-04/III/2010, UFRGS 4638; 4 males, 12 females, 1 manca, N5S07 cave, 606' S - 5008'W, 14-23/X/2009, UFRGS 4639; 1 male, 1 female, N5S10 cave, 60' S - 5008'W, 14-23/X/2009, UFRGS 4640; 1 male, N5S21 cave, 606' $50^{\circ} 08^{\prime} \mathrm{W}$, 14-23/X/2009, UFRGS 4641; 1 male, 4 females, N5S21 cave, 606' S - 5008'W, 25/ VIII-03/IX/2009, UFRGS 4642; 1 male, 4 females, N5S85 cave, 606' S - 5008'W, 25/ VIII-03/IX/2009, UFRGS 4643; 1 female, N5S14 cave, 606'S 5008'W, 25/VIII-03/ IX/2009, UFRGS 4644; 2 males, 2 females, N5S74 cave, 606'S - 5008'W, 25/VIII-03/ IX/2009, UFRGS 4645; 2 males, 1 female, N5S52/53 cave, 606'S 5008'W, 25/VIII-03/ IX/2009, UFRGS 4646; 1 male, N5S11 cave, 606'S - 5008'W, 14-23/X/2009, UFRGS 4647; 1 male, 1 female, N5S63/64/65 cave, $6^{\circ} 06^{\prime} S$ - 5008'W, 14/III-04/IV/2010, UFRGS 4648; 1 female, N5S14 cave, 606'S - 500' W, 14-23/X/2009, UFRGS 4649; 1 female, N5S71 cave, 6 6 $06^{\prime} S$ - 500.'W, 25/ VIII-03/IX/2009, UFRGS 4650; 1 female, 1 manca, N5S22 cave, 606'S - 5008'W, 25/ VIII-03/IX/2009, UFRGS 4651; 1 female, N5S19 cave, 606'S - 5008'W, 25/VIII-03/ IX/2009, UFRGS 4652; 1 female, N5S20 cave, 606'S - 5008'W, 25/VIII-03/IX/2009, UFRGS 4653; 1 female, N5S37 cave, 6 ${ }^{\circ} 06^{\prime}$ S - 500.'W, 15-21/IX/2009, UFRGS 4654; 1 male, 17 females, 1 manca, N4E33 cave, 606'S - 5008'W, 15-22/IX/2009, UFRGS 4655; 1 male, 8 females, 1 manca, N4E08 cave, 6 $6^{\circ} 06^{\prime} \mathrm{S}$ - 5008'W, 20/IV-04/V/2010, UFRGS 4656; 2 females, N4E85 cave, 606'S - 5008'W, 18/VIII-03/IX/2009, UFRGS 4657; 2 males, 3 females, N4E26 cave, 606'S - 5008'W, 18/VIII-03/IX/2009, UFRGS 4658; 1 male, 3 females, N4E28 cave, 606'S $50^{\circ} 08^{\prime} \mathrm{W}, 18 / \mathrm{VIII}-03 / \mathrm{IX} / 2009$, UFRGS 4659; 3 females, N4E73 cave, 606' $-50^{\circ} 08^{\prime} \mathrm{W}, 24-$ 30/VII/2009, UFRGS 4660; 1 female, N4E74 cave, 606's - 5008'W, 24-30/VII/2009, UFRGS 4661; 3 females, N4E82 cave, 606'S - 500ㅇ' W, 24-30/IX/2009, UFRGS 4662. 
Diagnosis: Pigment and eyes absent, antennule with 8 aesthetascs (in rows of two aesthetascs each), vestigial schisma on pereionite 1 in adults, restricted to a slight sinuosity, well marked in juveniles; distal article of flagellum longer than proximal article, apical organ longer than second article of antennal flagellum; dactylar organ with fringed apex with knife-shaped appearance.

Description: Male maximum body length $5.0 \mathrm{~mm}$, cephalothorax width $1.1 \mathrm{~mm}$; female maximum body length $5.3 \mathrm{~mm}$, cephalothorax width $1.2 \mathrm{~mm}$. Body pigment absent. Body convex, smooth (Figs. 1A, B). Cephalothorax wider than long, lateral lobes and eyes absent, presence of frontal shield continuous with pereionite 1 , linea frontalis delimiting superiorly the frontal shield, tenuous linea supra-antennalis. Pereion with pereionite 1 twice as long as pereionite 2, schisma present in juveniles (Figs. 1C, 7A-C) and absent in adults (Figs. 7D, E). Glandular pores and noduli laterales not visible. Pleon appearing continuous with pereion, neopleurae 3-5 well developed, anterior margin of pleotelson concave, lateral margins following the contour of neopleurae 3-5, distal margin rounded (Fig. 1D).

Appendages: Antennule triarticulate, distal article approximately four times as long as second article, with eight aesthetascs in three rows and with a small hook-like protuberance at the apex (Fig. 1E). Antenna short, when extended backward reaching approximately midlength of first pereionite, fourth and fifth articles more robust than others, distal portion with one long ornamental seta; antennal flagellum with two articles, distal article longer, around two times as long as proximal article, with 8-10 aesthetascs (faintly visible), apical organ longer than distal article and showing sensory hairs enclosed by a common tubelike sheath, and with simple short free sensilla (Fig. $1 F)$. Mandibles with at least seven branches on pars molaris, right mandible with two penicils on incisor process, and left mandible with three penicils (Figs. 1G, H). Inner endite of maxillula with two short penicils, inserted almost transversely, distal portion rounded with small hook-like protuberance, outer endite with 4 stout, simple setae, an accessory small tooth and a slender seta, and inner set with five teeth cleft, one simple, and slender (Fig. 1I). Lateral lobe of maxilla approximately three times broader than median lobe, distal margin slightly rounded, with trichiform setae; median lobe quadrate with distal margin rounded, and covered with trichiform setae (Fig. 1J). Maxilliped with rectangular base, sparse tricorn-like setae, and distal margin prominent with slender setate fringe, endite rectangular, with inner and outer lateral margins with slender setae, distal margin slightly prominent, inner portion with short penicil, and seta overpassing the margin, outer portion with one seta, palp tapering, with 3 tufts of setae, proximal article with 1 long inner seta (Fig. 1K). Pereiopods with typical scleropactid scale fields, sparse setae with gradual elongation, and apex tricorn and robust, carpus 1 with transverse antennagrooming brush and one hand-like apex seta, merus 7 without lateral ridge, dactylus with long outer and inner claws, ungual seta long with simple apex and reaching distal margin of outer claw, dactylar organ long with pectinate apex, conferring a knife-shaped appearance (Figs. 2A-C). Pleopods with respiratory fields faintly visible. Uropod with insertion of endopod and exopod at different levels, protopod enlarged, endopod two times longer than exopod, inner lateral margin with sparse setae with fringed appearance continuous with protopod, exopod insertion covered by protopod (Fig. 3E).

Male: pleopod 1 exopod with the distal margin slightly sinuous (Fig. 2D), endopod 1 bent outwards and bearing small setae (2E); pleopod 2 exopod triangular, outer lateral margin convex relative to insertion, rounded apex, sulcus marginalis present, endopod 2 slender, reaching pleopod 5, with apex curved and acute (Fig. 2F); pleopods 3 and 4 as in figures $3 \mathrm{~A}$ and $3 \mathrm{~B}$; pleopod 5 exopod triangular, distal part narrow and acute, covered with fringe 


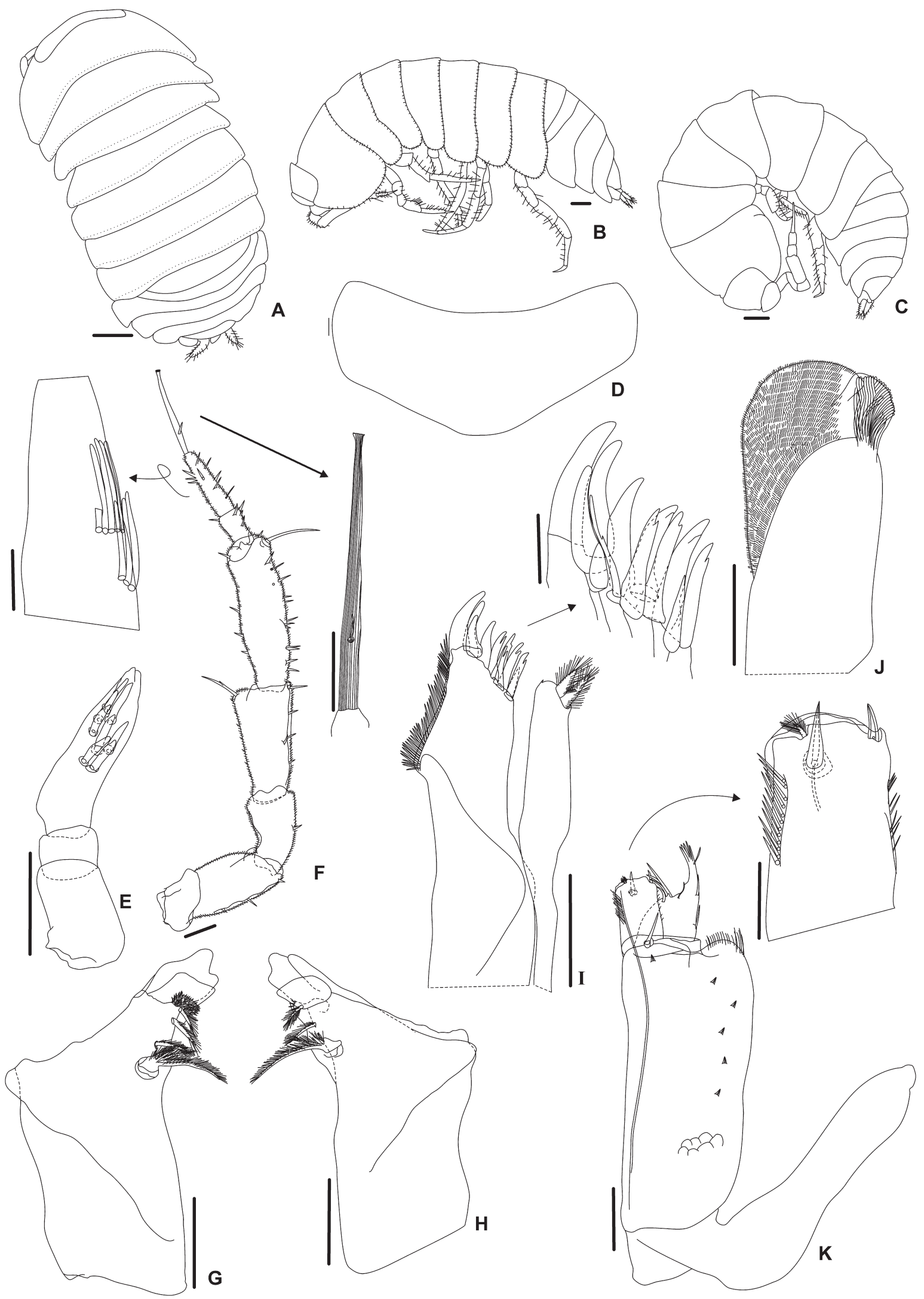

Figure 1. Circoniscus buckupi sp. nov., male paratype MZUSP 23756. A, dorsal view; B, lateral view; C, juvenile, lateral view; D, pleotelson; E, antennule; F, antenna; G, left mandible; H, right mandible; I, maxillula; J, maxilla; K, maxilliped. Scale bars: A, B, 0.5 $\mathrm{mm}$; C, $0.25 \mathrm{~mm}$; D-K, $0.1 \mathrm{~mm}$. 


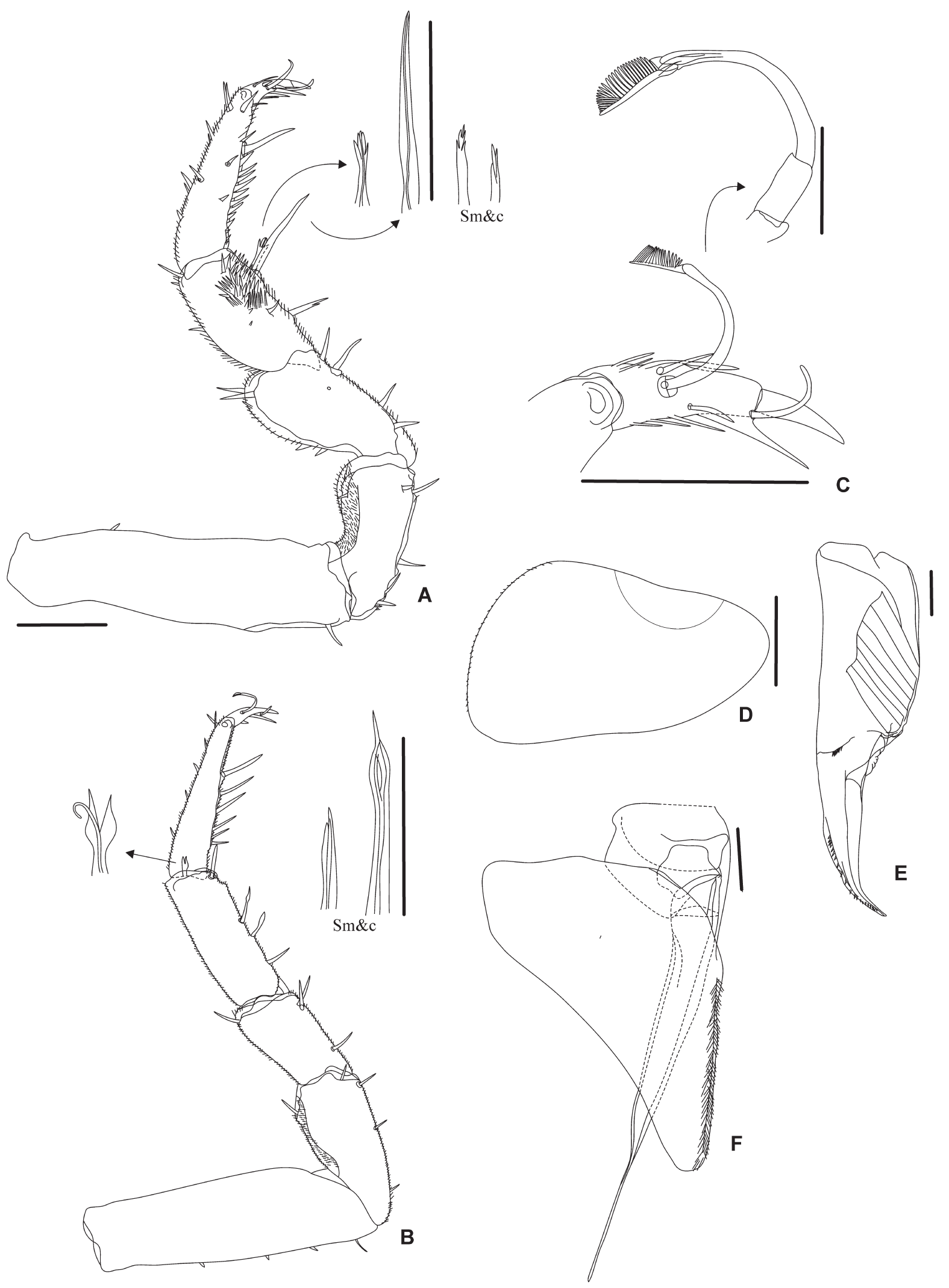

Figure 2. Circoniscus buckupi sp. nov., male paratype MZUSP 23756. A, pereiopod 1; B, pereiopod 7; C, dactylus; D, pleopod 1 exopod; E, pleopod 1 endopod; F, pleopod 2. Sm\&c: setae on merus and carpus. Scale bars: $0.1 \mathrm{~mm}$. 

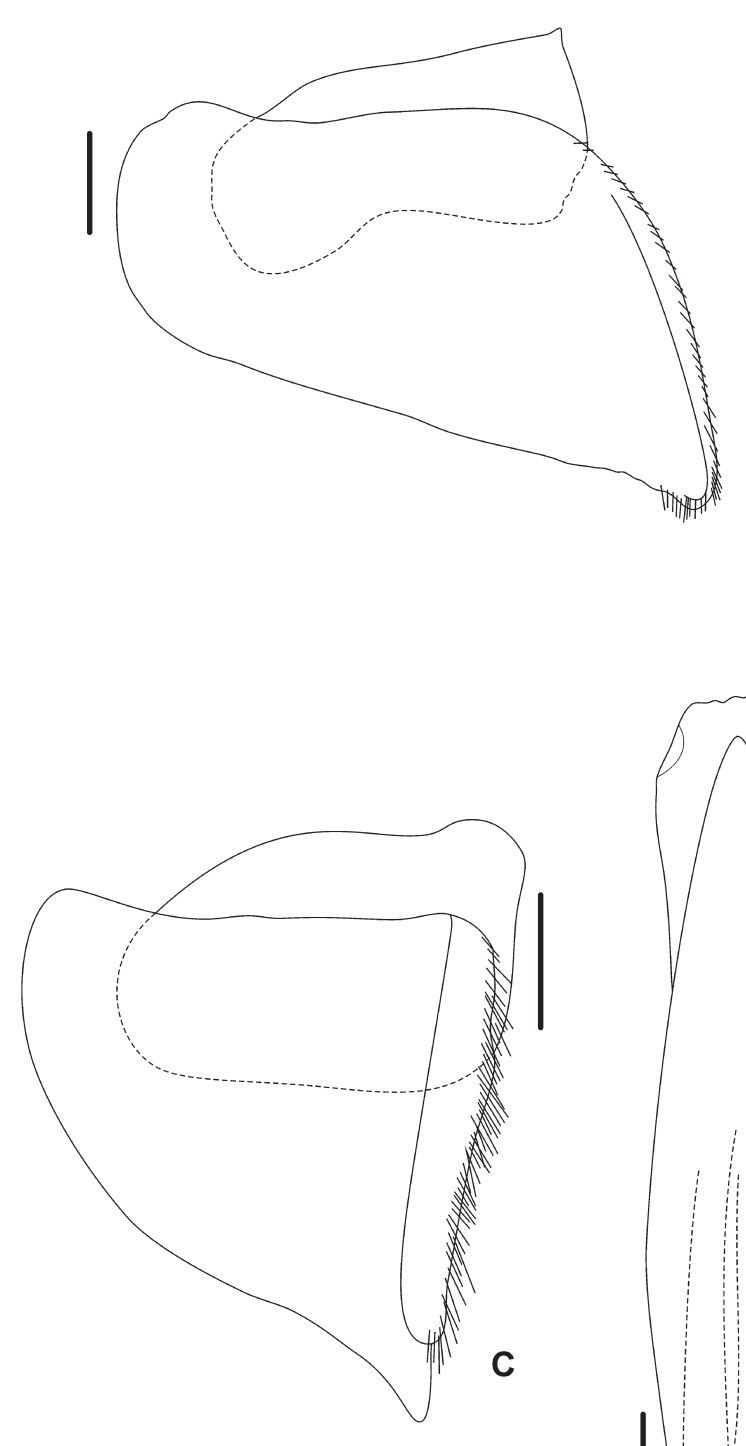

papilla; E, uropod. Scale bars: $0.1 \mathrm{~mm}$.

scales over half of length, and a longitudinal furrow to receive the pleopod 2 endopod (Fig. 3C). Genital papilla with ventral shield and two subapical orifices (Fig. 3D).

Sexual dimorphism: female pleopod 1 exopod more elongated than in male, pleopod 2 exopod and 5 with distal part not elongated.

Etymology: The species name honors Professor Ludwig Buckup for his contributions to the knowledge of Crustacea.

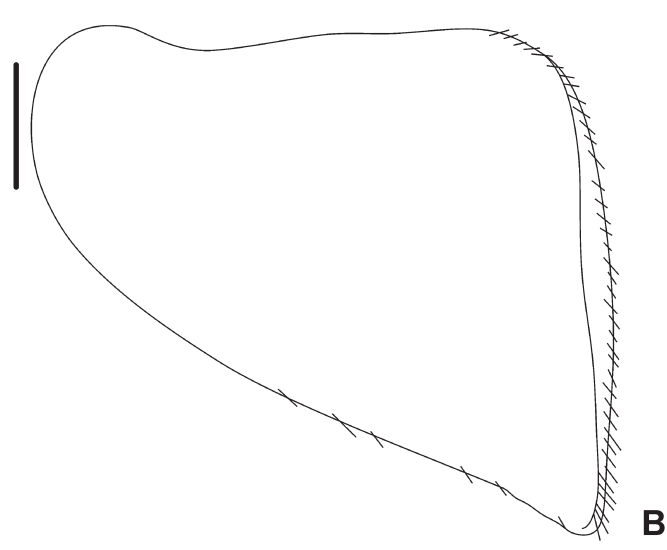

D

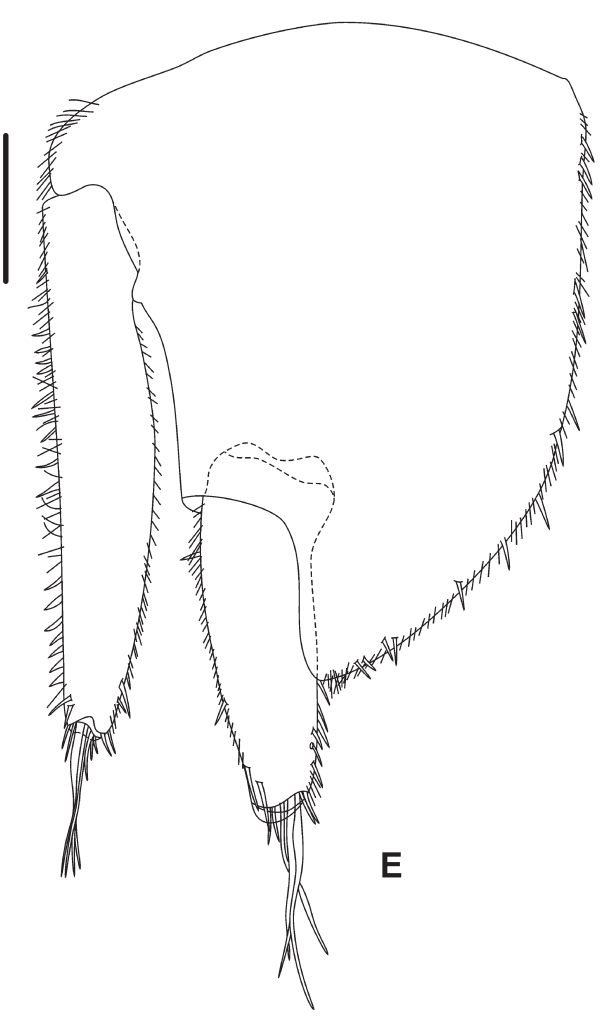

Figure 3. Circoniscus buckupi sp. nov., male paratype MZUSP 23756. A, pleopod 3; B, pleopod 4 exopod; C, pleopod 5; D, genital

Remarks: Circoniscus buckupi sp. nov. shares characteristics found in its congeners, such as the second antenna with flagellum biarticulate and the outer endite of maxilulle with inner set of cleft teeth. The new species can be distinguished by the absence of the schisma on pereionite 1 in adults, long second article of antennal flagellum, dactylar organ with pectinate apex conferring a knife-shape appearance, pleopod 1 exopod with the distal margin slightly sinuous and the respiratory fields faintly visible. The well developd schisma in young individuals allowed us to allocate the 
species in the genus Circoniscus. Thereby we consider that the absence of schisma in adults as a secondary loss of character.

\section{Circoniscus carajasensis sp. nov.} Figs. 4-7

Types - Holotype: male, Brazil, Pará: Canaã dos Carajás, S11-07 cave 6²7'20"S - 50¹4'29”W', 24/II-4/III/2010, MZUSP 23772. Paratypes: same locality as holotype, 2 males, 1 female, MZUSP 23773; 1 male, 1 female, MZUSP 23774; 1 male, 3 females, MZUSP 23775; 1 male, 5 females, MZUSP 23776; 5 males, 2 females, UFRGS 4568; 2 males, 2 females, UFRGS 4569; 1 male, 1 female, UFRGS 4570; 3 males, 2 females, 1 juvenile, UFRGS 4571.

Diagnosis: Pigment and eyes absent, antennule with $7+1$ aesthetascs, schisma on pereionite 1; apical organ longer than second article of antennal flagellum; dactylar organ with brush-like apex; pleopod 1 exopod ovoid.

Description: Male maximum body length $3.5 \mathrm{~mm}$, cephalothorax width 0.73 $\mathrm{mm}$, female maximum body length $4.0 \mathrm{~mm}$, cephalothorax width $1.02 \mathrm{~mm}$. Body pigment absent. Body convex, smooth (Figs. 4A, B). Endoantennal conglobation. Cephalothorax wider than long, lateral lobes and eyes absent, presence of frontal shield continuous with pereionite 1, linea frontalis bounded superiorly by frontal shield, tenuous linea supra-antennalis (Figs. 4C, D). Pereion with pereionite 1 twice as long as pereionite 2, with a schisma (Figs. 7F, G). Glandular pores and noduli laterales not visible. Pleon appearing continuous with pereion, neopleurae 3-5 well developed, anterior margin of pleotelson concave, lateral margins following the contour of neopleurae 3-5, distal margin rounded (Fig. 4E).

Appendages. Antennule triarticulate, distal article approximately three times as long as second article, with seven aesthetascs in rows (one group of three and two groups of two plus apical one) (Fig. 4F). Antenna short, when extended back reaching midlength of first pereionite, fourth and fifth articles of peduncle more robust than others, antennal flagellum with two subequal articles, distal article with 8-10 aesthetascs (faintly visible), apical organ longer than second article of flagellum, bearing sensory hairs enclosed by a common tubelike sheath, and with simple and short free sensilla (Fig. 4G). Mandibles with at least eight branches on pars molaris, right mandible with two penicils on incisor process (not illustrated), and left mandible with three penicils (Fig. 4I). Inner endite of maxillula with two short penicils, inserted almost transversely, distal portion rounded with small hook-like protuberance, outer endite with 4 stout, simple setae, an accessory small tooth and a slender seta, and inner set with five teeth cleft, one simple, and slender (Fig. 4J). Lateral lobe of maxilla twice as broad as median lobe, distal margin slightly sinuous, covered with trichiform setae, median lobe quadrate, distal margin slightly rounded and covered with trichiform-setae (Fig. 4K). Maxilliped with rectangular base, sparse tricorn-like, distal margin truncated, with slender setae fringe, endite rectangular, distal margin slightly prominent, with short penicil, setose lateral margin, outer portion with one seta and lateral margin with sparse setae; palp with three tufts of setae, proximal article with one long inner seta (Fig. 4L). Pereiopods with typical scleropactid scale-fields, sparse setae, merus and carpus 1 and 2 robust, carpus 1 with transverse antenna-grooming brush and two hand-like apex setae, merus 7 elongated, without a lateral ridge, dactylus with long outer claw, shorter inner claw, ungual seta long and simple, long dactylar organ, with brushlike apex, ungual and dactylar setae reaching distal margin of outer claw (Figs. 5A-C). Pleopods with respiratory fields faintly visible. Uropod with insertion of endopod and exopod at different levels, protopod enlarged, endopod two times longer than exopod, inner lateral margin with sparsely fringed appearance, continuous with protopod, exopod insertion covered by protopod (Fig. 6D). 

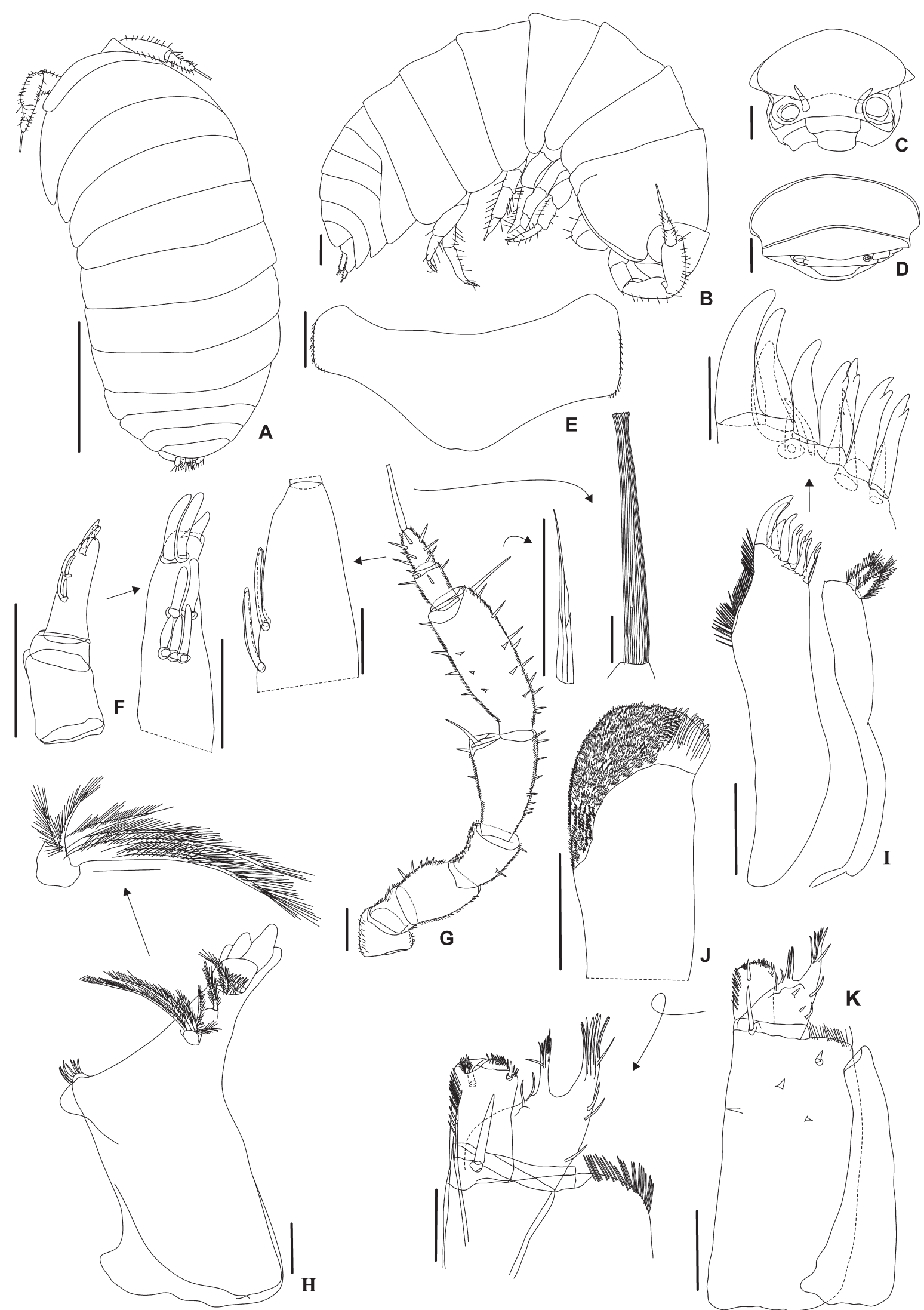

Figure 4. Circoniscus carajasensis sp. nov., male paratype MZUSP 23773. A, dorsal view; B, lateral view; C, cephalothorax frontal view; D, cephalothorax dorsal view; E, pleotelson; F, antennule; G, antenna; H, left mandible; I, maxillula; J, maxilla; K, maxilliped. Scale bars: A-D, $0.16 \mathrm{~mm}$; E-K, $0.1 \mathrm{~mm}$. 

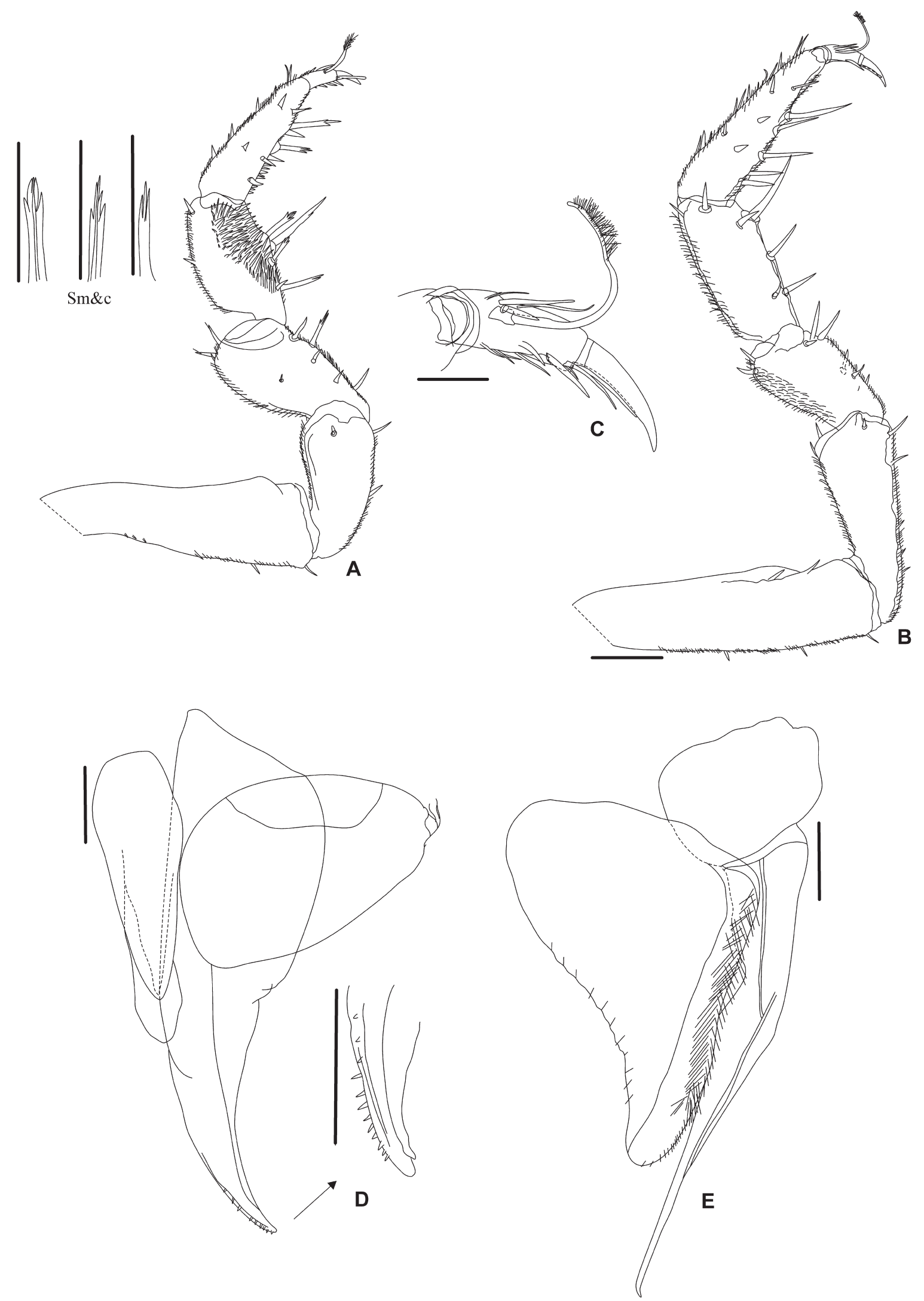

Figure 5. Circoniscus carajasensis sp. nov., male paratype MZUSP 23773. A, pereiopod 1; B, pereiopod 7; C, dactylus; D, pleopod 1 and genital papilla; E, pleopod 2. Sm\&c: setae on merus and carpus. Scale bars: $0.1 \mathrm{~mm}$. 

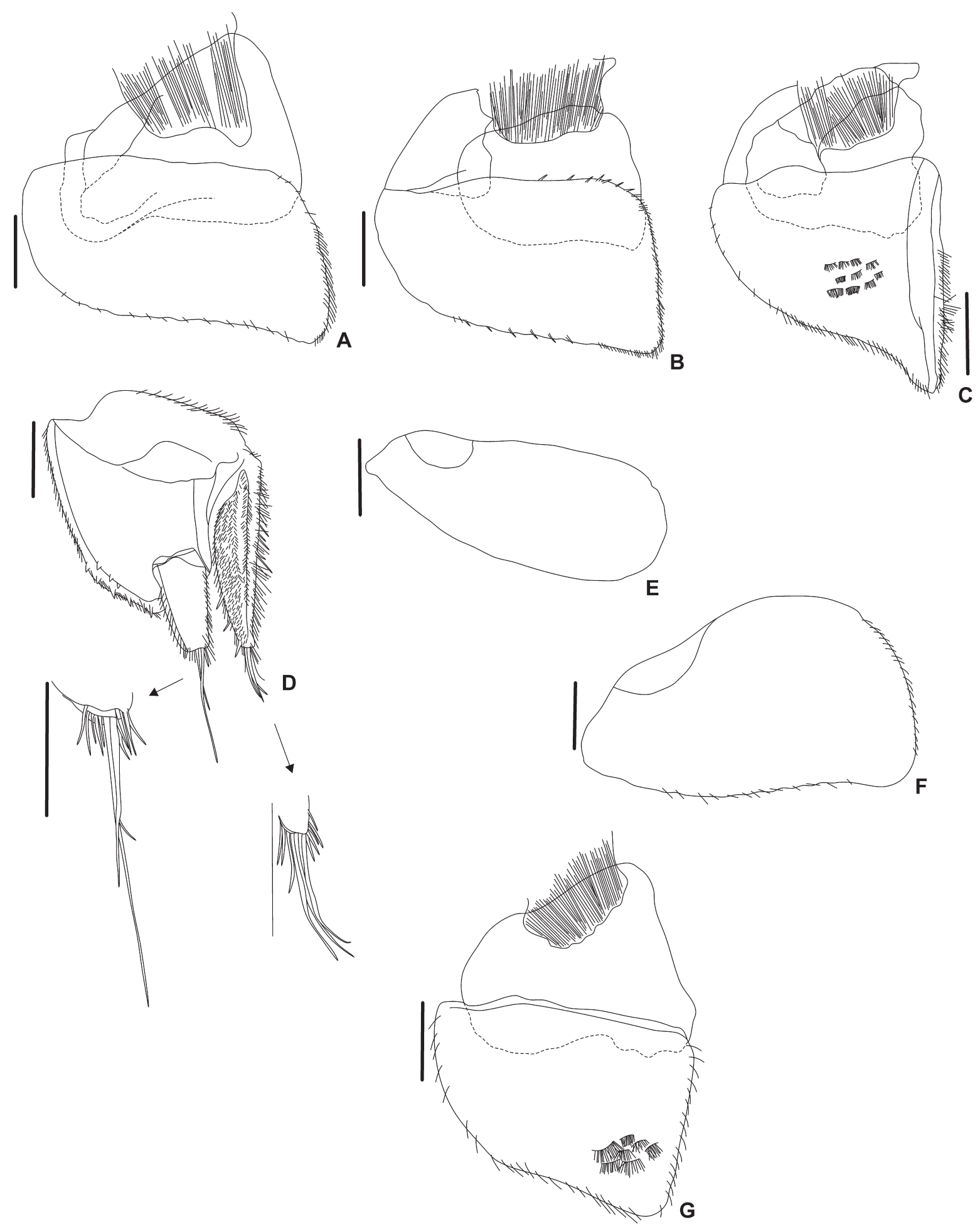

Figure 6. Circoniscus carajasensis sp. nov., male paratype MZUSP 23773. A, pleopod 3; B, pleopod 4; C, pleopod 5; D, uropod. Female paratype MZUSP 23773. E, pleopod 1 exopod; F, pleopod 2 exopod; G, pleopod 5. Scale bars: $0.1 \mathrm{~mm}$. 
Male: pleopod 1 exopod ovoid, with rounded apex, endopod 1 with small setae on distal part (Fig. 5D); pleopod 2 exopod triangular, outer lateral margin convex relative to insertion, rounded apex, sulcus marginalis present, endopod 2 slender, reaching pleopod 5, with apex curved and rounded (Fig. 5E); pleopods 3 and 4 as in Figures $6 \mathrm{~A}$ and 6B; pleopod 5 exopod triangular, distal part narrow, covered by fringe scales, and a longitudinal furrow to receive the pleopod 2 endopod (Fig.
6C). Genital papilla with ventral shield and two subapical orifices (Fig. 5D).

Sexual dimorphism. Female pleopod 1 exopod more elongated than in male, pleopod 2 exopod and pleopod 5 exopod with distal part not elongated as in males (Figs. 6E-G).

Etymology: The species name refers to the location where the specimens were collected: FLONA (National Forest) - Carajás.

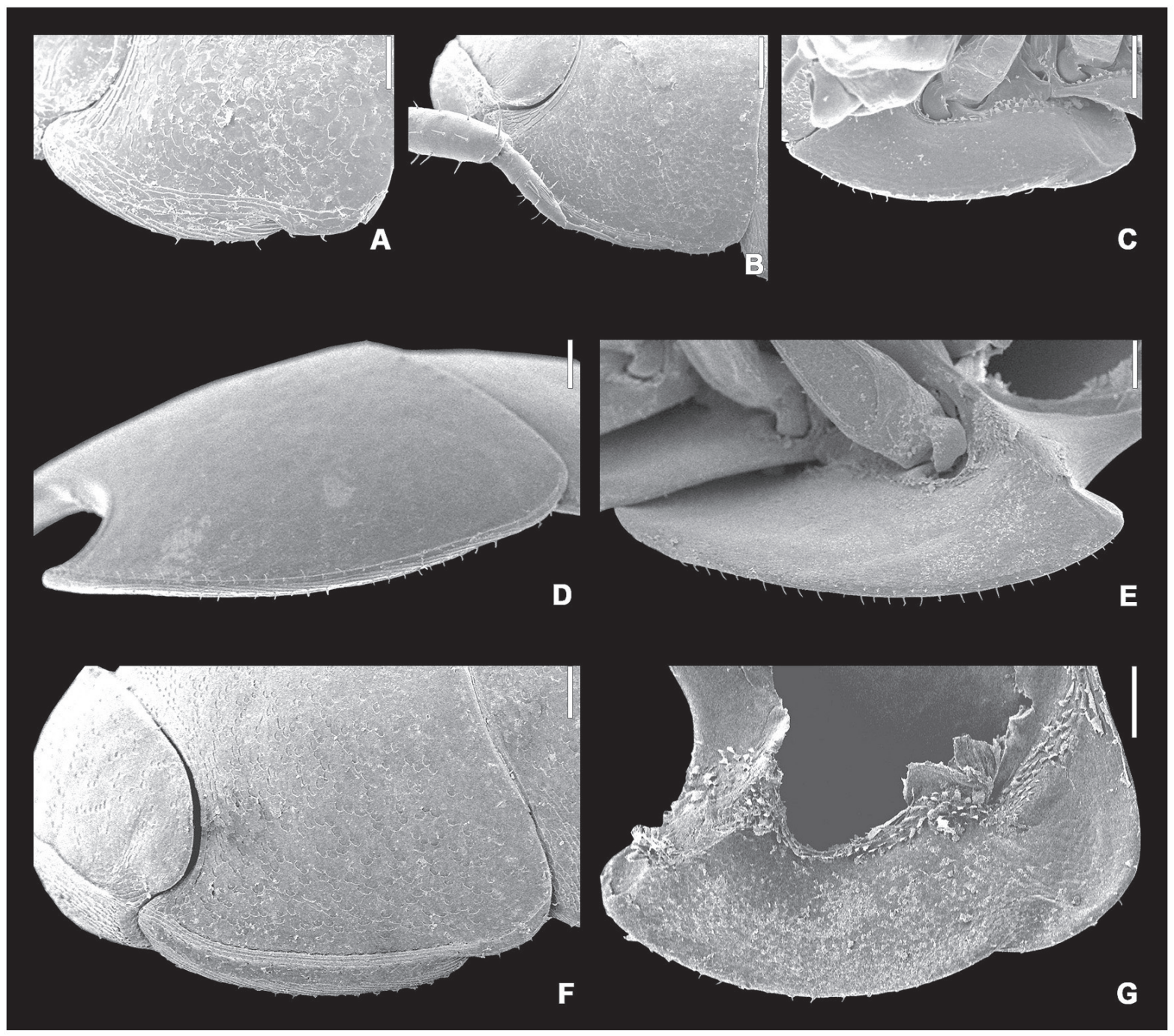

Figure 7. Circoniscus buckupi sp. nov., A, B, juveniles, pereionite 1 dorsal view; C, juvenile, pereionite 1 ventral view; D, adult, pereionite 1 dorsal view; E, adult, pereionite 1 ventral view. Circoniscus carajasensis sp. nov., F, pereionite 1 dorsal view; G, pereionite 1 ventral view. Sacale bars: A, $50 \mu \mathrm{m}$; B-G, $100 \mu \mathrm{m}$.

Remarks: Circoniscus carajasensis sp. nov. shares characteristics with its congeners such as the coxal plate 1 with schisma, second antenna with flagellum bi-articulate, and outer endite of maxilulle with inner set of cleft teeth. The new species can be distinguished from the other troglobitic species, Circoniscus buckupi sp. nov. by the presence of schisma on pereionite 1 , dactylar organ with a fringe appearance and the ovoid shape of the pleopod 1 exopod. 


\section{Acknowledgments}

We are grateful to Regina Bessi and Renata Andrade for donating the specimens, to CAPES (Coordenação de Aperfeiçoamento de Pessoal de Nível Superior) for a scholarship to ISCF and to CNPq (Conselho Nacional de Desenvolvimento Científico e Tecnológico) for a productivity fellowship to PBA.

\section{References}

Leistikow, A. 2001. Phylogeny and biogeography of South American Crinocheta, traditionally placed in the family "Philosciidae" (Crustacea: Isopoda: Oniscidea). Organisms, Diversity \& Evolution, 4(1):1-85.

Pearse, A. 1917. Isopoda collected by the Bryant Walker Expedition to British Guiana, with notes on Crustacea from other localities. Occasional Papers of the Museum of Zoology of University of Michigan, 46:1-8.

Schmalfuss, H. 2003. World catalog of terrestrial isopods (Isopoda: Oniscidea). Stuttgarter Beiträge zur Naturkunde, 654:1341. Available from: http://www.oniscideacatalog.naturkundemuseum-bw.de/Cat_ terr_isop.pdf. (25 August 2010).

Schmidt, C. 2002. Contribution to the phylogenetic system of the Crinocheta (Crustacea: Isopoda). Part 1. (Olibrinidae to Scyphacidae s. str.). Zoologische Reihe, 78 (2):275-352.

Schmidt, C. 2003. Contribution to the phylogenetic system of the Crinocheta (Crustacea: Isopoda). Part 2. (Oniscoidea to Armadillidiidae). Zoologische Reihe, 79 (1):3-179.

Schmidt, C. 2007. Revision of the Neotropical Scleropactidae (Crustacea: Oniscidea). Zoological Journal of the Linnean Society, 151(1):1-339.

Schmidt, C. 2008. Phylogeny of terrestrial Isopoda (Oniscidea): a review. Arthropod Systematics \& Phylogeny, 66(2):191-226.
Souza, L.A. and Lemos de Castro, A. 1991. The genus Circoniscus Pearse 1917 in Brazil, with description of three new species (Isopoda Oniscidea Scleropactidae). Tropical Zoology, 4:45-64.

Souza, L.A.; Bezerra, A.V. and Araujo, J.P. 2006. The first troglobitic species of Scleropactidae from Brazil (Crustacea, Isopoda, Oniscidea). Subterranean Biology, 4: $37-43$.

Taiti, S. 2004. Crustacea: Isopoda: Oniscidea (woodlice). p. 547-551. In: Gunn, J. (ed), Encyclopedia of caves and karst science, New York, Fitzroy Dearborn, Taylor and Francis Group. 